\title{
25 \\ How Can Collaborative Research be More Useful to Fisheries Management in Developing Countries?
}

\author{
C. E. Nauen
}

\begin{abstract}
Most fisheries management schemes in industrialised and developing countries have not delivered sustainability, the goal usually pursued by them. This short communication takes a look at some ways in which collaborative research and the mobilisation of a wider range of societal actors, such as promoted under the ACP-EU Fisheries Research Initiative, can make a more useful contribution to fisheries management in developing countries.
\end{abstract}

\section{Introduction}

Most fisheries management schemes in industrialised and developing countries have not delivered sustainability, the goal usually pursued by them. Garcia and Newton (1997) pointed out that 70 per cent of the world's marine capture fisheries are overexploited, fully exploited or recovering. As Gréboval and Munro (1999) state in their introduction to an FAO Fisheries Technical Paper based on a Technical Working Group on the Management of Fishing Capacity, convened in La Jolla, USA from 15-18 April 1998: "Regardless of how one chooses to interpret the term 'fully exploited', there are substantial grounds for expressing deep concerns about the state of world capture fishery resources." A series of recent publications add quantitative analyses and new perspectives to the crisis in fisheries (e.g. Pauly et al. 1998a; Christensen 2001; Froese and Reyes, in prep.).

We therefore see more scepticism about research and applications, which confine themselves purely to the 'technical' aspects of fisheries management. These and the underlying 'reductionist' attitudes have been contributing factors to major fishery collapses and a generalised decline in ecosystem health.

On closer examination, the economics and incentive systems at work are believed to neutralise if not pervert many management attempts. Imperfect markets appear to mask scarcity effects as fish prices of previously undesirable species have increased in price relatively faster than now much scarcer 'high value' species (mostly ground fish and large pelagics) much reduced by overfishing, but which have maintained or only moderately increased their market prices (Sumaila 1999; Sumaila et al., 2000). The information allowing investors in fisheries to make better economic decisions is found lacking (Des Clers 1998) and this shortcoming appears to be of concern for other stakeholders as well. Most recently, Watson and Pauly (2001) showed that global marine catches have declined since reaching a peak of about 80 million tons in the late 80 s instead of increasing as official world statistics have misled us into believing. Misreported national statistics were disseminated through FAO which, as an intergovernmental organisation, relies on official national communications. This may have unwisely influenced planners and investors alike. 
But perhaps equally importantly, the mechanisms are largely underdeveloped, which would allow more effective dialogue between sector stakeholders to create conditions for the success of management. The gap between the broad principles of the FAO Code of Conduct for Responsible Fisheries (FAO 1995), the demand for ecosystem-based management as incorporated in the Jakarta Mandate agreed by the 1995 Conference of the Parties to the Convention of Biological Diversity (http://www.biodiv.org/decisions/default.asp?lg=0\&m=cop02) and the harsh realities of depleted resources, degraded ecosystems (Pauly et al. 1998a), loss of productivity and aquatic diversity (Froese and Torres 1999), remains unbridged so far. Some of the issues may be illustrated through the case of a co-operation project sponsored under the Fisheries Research Initiative between African, Caribbean and Pacific (ACP) Countries and the European Union (Anon. 1995, 1996, 1997a, 1997b).

\section{Missing Links}

The Project 'Strengthening of Fisheries and Biodiversity Management in ACP Countries' set out specifically to make FishBase and related analytical tools available to African, Caribbean and Pacific (ACP) partners enriching it through collaboration. More generally it was to contribute to a positive environment for ACP participants under the ACP-EU Fisheries Research Initiative. Interaction with ACP researchers and fisheries administrators during the years of implementation illustrate a number of obstacles in the way of effective biodiversity and resource management. With the benefit of hindsight, these seem not to be confined to the project itself but to be indicative of a more generalised set of problems in relation to fisheries management in many developing countries.

Fisheries departments are usually responsible for fisheries management in their respective countries; however, closer examination reveals a lack of means and an unsatisfactory institutional framework to carry out their mandate. Indeed, others may de facto influence decisions, which would be incumbent on the fisheries department or other departments of the ministry overseeing fisheries rather than those who are directly in authority. There are cases in which fisheries departments lumbered with conflicting mandates of 'extension' and 'law enforcement' are hindered in delivering either effectively. Environment and resource conservation is only gradually perceived as offering the most interesting opportunities for socioeconomic development. In most cases, the human resources, institutional arrangements and budgets available for management and sector policy fall short of what is necessary. Training and retraining of fisheries officers are often found wanting when faced with the evolving nature of the task at hand.

Finally, to embed fisheries management in the wider picture, it should be mentioned that macro-economic demands are frequently put onto the sector administration without it being equipped institutionally and politically to handle them (Cunningham pers. comm.). Conversely, macro-economic decisions impact the fisheries sector, sometimes even more so than sector management (Dahou and Deme 2001). This socio-economic connectivity is, however, not further developed here.

Fishers themselves, small- and large-scale alike, though to different degrees, may not feel bound by the management scheme in place, if any, to contribute their share to long-term sustainability, when shorter-term cash flow or even survival problems loom large. Other 
stakeholders tend to have little or no representation on any formal scheme. Among these, fish processors and traders, who, especially at the small-scale level are often women, may come to mind easiest. But conservationists and consumers are equally legitimate stakeholders with significant interest in long-term productivity of the resources.

Researchers working on the fisheries sector, including its ecological and socio-economic framework, should interact with all of them, though this has not always happened in the past. Research in many tropical and sub-tropical countries is insufficiently funded to make the contributions towards the overall goal of sustainable fisheries expected of them given the importance of aquatic resources and resource use in many economies. This may be aggravated by insufficient collaboration between universities, sector institutes depending on ministries in charge of fisheries, and even other research establishments or documentation centres. Each of these bodies addresses part or all of the ecological and socio-economic issues, on which decision makers need information and understanding.

The sample of stakeholders mentioned does not necessarily represent homogeneous groups, but a broad-brush picture leaving their internal subtle differences, complementarities and conflicts aside.

All too often, conservationists and fishers have identified with group interests perceived as diametrically opposed with little communication existing between them. Consumers are increasingly remote from production as indicated by the high percentage of fishery products entering global trade (FAO 2000). Since the establishment and enforcement of stricter health standards in the major import markets (Japan, European Union and North America) in the mid 1990s, worries have sometimes been aired that consumers and the veterinary inspection services in these import markets are more concerned with their own food safety than with the living conditions of the original producers (eg Jansen 1997).

These are but highlights on some of the fault lines. There is no shortage of attempts to establish better communication or to improve information exchange. However, the missing links enabling a reversal of the downward course of fisheries have so far been elusive.

\section{What Could Make a Difference?}

The dialogue, which laid the foundations of the ACP-EU Fisheries Research Initiative, showed the potential for relationships of voluntary co-operation based on mutual respect and shared responsibility (Anon. 1997b). It underscored needs for foresight and scientific pro-activeness.

There is also increasing realisation that foresight and pro-activeness depend on a good understanding of the history of the ecosystem or society under study (Putman 1993; Pauly 1995; Pauly et al. 1998c; Nauen 1998a). Two scientific conferences at EXPO 98 under the Fisheries Research Initiative made contributions to address the historical dimension (Pauly et al. 1999, Pullin et al. 1999). This has so far attracted little attention in the context of management, concerned as it is with solving problems on a short-term scale. However, without an understanding of the history of a system no baseline exists to appreciate the range of options for decision making enabling socio-economic and ecological sustainability.

These considerations bring home yet again the need for transdisciplinary work in recognition of the complexity around us. Yet, piecing the picture together and particularly how to deal with uncertainty and risk, opens many new questions. 
In the biological and ecological fields, FishBase makes available information on all 25,000 finfish in the world. The information spans many disciplines and is structured around species and their higher taxonomic aggregates as they represent current understanding of evolution (Froese and Pauly 2000). The data structure allows different 'communities' of stakeholders to draw on the database's content (and enrich it with their own specific data and knowledge, by now even through remote data entry for experts assuring quality control). It enables them to carry out their preferred types of analysis on a broader quantitative basis than they would be able to do in isolation. Experienced users thus gain new insights into their own fields and their limits, allowing them also to venture into other areas of information and analysis.

The core data are available on the Internet http://www.fishbase.org The site now attracts some 150,000 users per month. Many of the website visitors are from industrialised countries. The spread of the Internet in developing countries and increased emphasis on language translation is bound to increase access there beyond their current share of about $25 \%$ of users. To compensate for remaining logistical problems, several thousand conventional CD ROMs have been shared with project partners and other interested individuals and institutions over the last few years. Froese (2001) summaries some key lessons underlying the success so far.

There are a few emerging lines, where the existing collaboration allows the development of new or complementary analytical tools responding to user needs. Extracting data and indicators relevant to ecosystems modelling such that fishery resources can be analysed in their ecosystem context enables researchers to ask new management questions (Christensen 1996; Christensen 1997). Thanks to these new concepts and outreach initiatives, managers and the public can assess fisheries in a different light.

Another opening was developed by Sumaila's analysis of price trends in fisheries products (1999) to probe not only the market equivalent of ecosystem changes provoked by fisheries, but also the role of protected areas as hedges against uncertainty (1998). Other areas of importance, e.g. particularly the less-developed areas of analysing the social costs of fisheries and policy research warrant future collaborative efforts. These and several other promising avenues can best be explored through collaborations, which build on the existing knowledge and develop it further under the guiding principles of the Research Initiative.

The uncertainty associated with the complexities of the large marine ecosystems, environmental forcing factors and the interconnectedness of sub-systems (eg through global scale oscillations) have implications on fisheries management (e.g. Durand et al. 1998; Bakun 1998). While enriching the research agenda is overdue, the inherent uncertainty in fisheries resource systems warrants a priori recognition that assessments cannot reasonably be expected for all resources and that consequently management approaches need careful rethinking (e.g. Walters 1998).

This also returns us to the initial question of who the legitimate stakeholders are and how to devise institutions that enable the transition from top-down fisheries management towards greater societal participation (McGlade 1994; Nauen et al. 1996; Adams 1997; Chakalall et al. 1997; Fontenelle 1997; Ruddle 1997). 


\section{Society's Increased Expectations in Relation to Research and the Role of Dialogue}

There is convergence in the analyses that legitimate parties in fisheries are not just in the triangle between the fisheries administration, 'fishermen' and research. Each of these three poles is differentiated depending on the actual economic and institutional conditions and possibilities. New actors have already entered the scene (Nauen 1999), foremost in the continuum from smallscale to international interest in processing, handling and trade. The latter is a powerful, and often controversial, driving force with leverage throughout the sector and beyond. More visible for the general public, local, national and international NGOs promoting environment and biodiversity conservation have espoused reduced fishing on global and local scales.

As far as the on-going collaboration under the FishBase Project is concerned, it is acknowledged that it has not yet led to any reversal in the downward trend in fisheries and biodiversity. The project has compiled substantial amounts of relevant information, made them available through a user-friendly interface, promoted new concepts and reached many of the institutional users in ACP countries as intended (Froese et al. 1999). But this is not enough.

The concepts and approaches promoted under this specific project are still relatively new to many partners and need to be more fully appropriated, in order to engender significant impact (see e.g. Fontenelle 1997). Intensified capacity building of ACP institutions, ACP-EU collaboration is the natural response to seek more visible impact in terms of rehabilitated fisheries and reduced threat to aquatic biodiversity.

In general terms, research itself will have to evolve in the process not only in terms of advancing scientific knowledge but also by interacting more with society under the partnership concept for a truly 'New Deal' (Viegas 1999). Indeed, new governance institutions as advocated in Kooiman (1997) invite the recognition of all stakeholders as providers and users of information and knowledge, new arrangements in the relations based on mutual respect.

With the recognition of the complexity of the aquatic and socio-economic systems, their spatial and temporal scales and dynamics, the role of research and knowledge can thus only increase. Approaches, such as the establishment of protected areas, are new options for managers to rehabilitate lost productivity (Roberts et al. 2001). Therefore, approaches to fisheries management must and can change. So great is the convergence between the general analysis and fisheries that new institutions and a 'New Deal' have also been demanded in fisheries management (Pauly et al. 1998b; Nauen, 1999).

Building on the good foundations of the ongoing co-operation, a strengthened ACP-EU initiative could support the wider appropriation of these new concepts and selectively help those local stakeholders, countries or regions, which have already invested in fisheries rehabilitation or will be doing so. The skills and competencies developed under the present project and other complementary ones of local and external partners would then combine to have a visible impact on fisheries. It is time to turn around some 'real life' fisheries onto a sustainable path.

\section{Acknowledgements}

The author warmly acknowledges the wide-ranging and critical discussions of the ACP-EU Steering Committee of the Project 'Strengthening of Fisheries and Biodiversity Management in ACP Countries', which contributed to the present short communication. The Steering Committee 
is composed of Timothy Adams, Eduardo Balguerias, Boris Fabres, Maria Luisa Cassama Ferreira/Amadu Bailo Camara, Guy Fontenelle, Thomas Maembe, Jean Calvin Njock, Helge Paulsen and chaired by the author. The Project's Principal Science Advisor, Daniel Pauly and Senior FishBase Project staff significantly contributed to these debates, namely Rainer Froese, Maria Lourdes (Deng) Palomares and Jan Michael Vakily. The original manuscript was written in 1999 and only slightly up-dated in 2001. Any mistakes remain the author's sole responsibility.

\section{References}

Adams, T. 1997 Governance of fisheries and aquaculture in the Pacific Islands region. Annex 12 pp. 165-180 In: Anon. ACP-EU Fisheries Research Initiative. Proceedings of the Third Dialogue Meeting, Caribbean, Pacific and the European Union. Belize, Belize City 5-10 December 1996. ACP-EU Fish.Res.Rep.,(3).

Anon. 1995 ACP-EU Fisheries Research Initiative. Proceedings of the First Dialogue Meeting. Eastern and Southern Africa, Indian Ocean and the European Union. Swakopmund, Namibia 5-8 July 1995. ACP-EU Fish.Res.Rep.,(1):144.

Anon. 1996 ACP-EU Fisheries Research Initiative. Proceedings of the Second Dialogue Meeting. West and Central Africa and the European Union. Dakar, Senegal 22-26 April 1996. ACP-EU Fish.Res.Rep.,(2):166 p.

Anon. 1997a ACP-EU Fisheries Research Initiative. Proceedings of the Third Dialogue Meeting. Caribbean, Pacific and the European Union. Belize, Belize City 9-11 July 1997. ACP-EU Fish.Res.Rep.,(3):180 p.

Anon. 1997b ACP-EU Fisheries Research Initiative. Proceedings of the Fourth Dialogue Meeting. All ACP Regions and the European Union. Brussels, Belgium 9-11 July 1997. ACP-EU Fish.Res.Rep.,(4):51 p.

Bakun, A. 1998 Ocean triads and radical interdecadal variation: bane and boon to scientific fisheries management. Chapter 25 pp. 331-358. In: Pitcher, T.J., P.J.B. Hart and D. Pauly (eds.). Reinventing fisheries management. Dordrecht, Boston, London, Kluwer Academic Publishers, Fish and Fisheries Series, 23.

Chakalall, B., R. Mahon and P. McConney 1997 Fisheries governance in the Caribbean. Annex 11 pp. 131-163. In: Anon. ACP-EU Fisheries Research Initiative. Proceedings of the Third Dialogue Meeting, Caribbean, Pacific and the European Union. Belize, Belize City 5-10 December 1996. Brussels, ACP-EU Fish.Res.Rep.,(3).

Christensen, V. 1996 Managing fisheries involving predator and prey species. Rev. Fish Biol. Fish., 6:417-442.

Christensen, V. 1997 Placing fisheries resources in their ecosystem context. EC Fish.Coop.Bull./Bull.Coop. Pêche CE, 10(2):9-11.

Christensen, V., 2001100 years ICES: Where are the stocks? Poster presented at the ICES Centenary Science Conference, Oslo, Norway, 26-29 September 2001

Dahou, K. et M. Deme (éds.) 2001 Impacts socio-économiques et environnementaux des politiques liées au commerce sur la gestion durable des ressources naturelles: Etude de cas sur le secteur de la pêche sénégalaise. Environnement et Développement du Tiers Monde (ENDA) avec la collaboration de Centre de Recherche Océanographique de Dakar Thiaroye (CRODT), 67 p. + annexes 
Des Clers, S. 1998 Information required by fishermen. EC Fish.Coop.Bull./Bull.Coop. Pêche CE, 11(3-4):34-37.

Durand, M.H., P. Cury, R. Mendelssohn, A. Bakun, C. Roy and D. Pauly (eds.) 1998 Global versus local changes in upwelling areas. Paris, ORSTOM, Série Colloques et Séminaires, 594 p.

FAO 1995 Code of conduct for responsible fisheries. Rome, FAO, 41 p.

FAO 2000 La situation mondiale des pêches et de l'aquaculture 2000. Rome, FAO, 142 p.

Fontenelle, G. (ed.) 1997 Activités halieutiques et développement durable. Actes du Colloque "Les Rencontres halieutiques de Rennes", 14-15 mars 1997. Rennes, Ecole Nationale Supérieure Agronomique de Rennes/Halieutique and Association Agro-Halieutes, 168 p. + Annexes.

Froese, R. 2001. The FishBase information system: key features and approaches. pp. 36-38 In: Feoli, E. \& C.E. Nauen (eds.). Proceedings of the INCO-DEV International Workshop on information systems for policy and technical support in fisheries and aquaculture. Los Baños, Philippines, 5-7 June 2000. ACP-EU Fish.Res.Rep., (8):135 p.

Froese, R., E. Capuli and D. Pauly 1999 The FishBase Project eight years after: Progress, impact and future directions. Http://www.fishbase.org/download/fbimpact6.zip (18 pages).

Froese, R. and A. Torres, 1999. Fishes under threat. An analysis of the fishes on the 1996 IUCN Redlist. pp.131-144 In: Pullin, R.S.V., D.M. Bartley and J. Kooiman (eds.). Towards policies for conservation and sustainable use of aquatic genetic resources. ICLARM Conf. Proc., 59:277 p.

Froese, R. and D. Pauly (eds.) 2000. FishBase 2000: Concepts, Design and Data Sources. Los Baños, Philippines, ICLARM, 346 p. (Distributed with 4 CD-ROMs)

Froese, R. and K. Reyes in prep. Boom and bust: Trends in world fisheries.

Garcia, S.M. and C. Newton 1997 Current situation, trends and prospects in world capture fisheries. pp. 7-27 In: PiKitch, E.K., E.D. Huppert and M.P. Sissenwine (eds.). Global trends: fisheries management. American Fisheries Society Symposium 20, Bethesda, MD, American Fisheries Society.

Gréboval, D. and G. Munro 1999 Overcapitalization and excess capacity in world fisheries: underlying economics and methods of control. Chapter 1 pp. 1-45 In: Gréboval, D. (ed.). Managing fishing capacity. Selected papers on underlying concepts and issues. FAO Fish.Tech.Pap., 386.

Jansen, E.G. 1997 Rich fisheries - poor fisherfolk. Some preliminary observations about the effects of trade and aid in the Lake Victoria fisheries. IUCN Eastern Africa Programme Report, No. 1:16 p.

McGlade, J.M. 1994 Governance of fisheries and aquaculture. Keynote address to the 1994 Statutory Meeting of the International Council of the Exploration of the Sea (ICES). Copenhagen, ICES, $26 \mathrm{p}$.

Nauen, C.E. 1998a Editorial. EC Fish.Coop.Bull./Bull.Coop. Pêche CE, 11(2):2.

Nauen, C.E. 1998b New approaches to development cooperation in capture and culture fisheries. pp. 30-39 In: Williams, M.J. (ed.). A roadmap for the future for fisheries and conservation. ICLARM Conf.Proc.,56. 
Nauen, C.E. 1999 New players make a mark in ocean governance. Int.J.Sustain.Dev.,2(3):382387.

Nauen, C.E., N.S. Bangoura and A. Sall 1996 Governance of aquatic systems in West and Central Africa: Lessons of the past, prospects for the future. Annex 11 pp. 147-160. In: Anon. ACP-EU Fisheries Research Initiative. Proceedings of the Third Dialogue Meeting. Caribbean, Pacific and the European Union. Belize, Belize City 5-10 December 1996. Brussels, ACP-EU Fish.Res.Rep.,(3).

Pauly, D. 1995 Anecdotes and the shifting baseline syndrome of fisheries. Trends Ecol.Evol., 10:430.

Pauly, D., V. Christensen, J. Dalsgaard, R. Froese and F. Torres Jr. 1998a Fishing down marine foodwebs. Science, 279:860-863.

Pauly, D., P.J.B. Hart and T.J. Pitcher 1998b Speaking for themselves: new acts, new actors and a New Deal in a reinvented fisheries management. Chapter 31 pp. 409-415 In: Pitcher, T.J., P.J.B. Hart and D. Pauly (eds.). Reinventing fisheries management. Dordrecht, Boston, London, Kluwer Academic Publishers, Fish and Fisheries Series, 23.

Pauly, D., T.J. Pitcher and D. Preikshot (with assistance of J. Hearne) (eds.) 1998c Back to the future: Reconstructuing the Straits of Georgia ecosystem. Vancouver, UBC Fisheries Centre Research Reports, 6(5):99 p.

Pauly, D., V. Christensen and L. Coelho (eds.) 1999 Ocean food webs and economic productivity. Proceedings of the EXPO 98 Conference, Lisbon, Portugal 1-3 July 1998. ACP-EU Fish.Res.Rep.,(5):87 p.

Pullin, R.S.V., R. Froese and C.M.V. Casal (eds.) 1999 Proceedings of the Conference on Sustainable Use of Aquatic Biodiversity: Data, Tools and Cooperation. Lisbon, Portugal 3-5 September 1998. ACP-EU Fish.Res.Rep.,(6):71 p.

Putman, R.D. 1993 Democracy, development, and the civic community: evidence from an Italian experience. pp. 33-73 In: Serageldin, I. And J. Tabaroff (eds.) Culture and Development in Africa. Proceedings of an International Conference held at the World Bank, Washington, DC April 2 and 3 1992. World Bank Env. Sustainable Develop.Proc.Ser., 1 .

Roberts, C.M., J.A. Bohnsack, F. Gell, J.P. Hawkins and R. Goodridge 2001 Effects of marine reserves on adjacent fisheries. Science, 294:1920-1923.

Ruddle, K. 1997 The role of local management and knowledge systems in ICAM in the Pacific Region: a review. Annex 10 pp. 121-130 In: Anon. ACP-EU Fisheries Research Initiative. Proceedings of the Third Dialogue Meeting. Caribbean, Pacific and the European Union. Belize, Belize City 5-10n December 1996. Brussels, ACP-EU Fish.Res.Rep.,(3).

Sumaila, U.R. 1998 Protected marine reserves as hedges against uncertainty: an economist's perspective. Chapter 23 pp. 303-309 In: Pitcher, T.J., P.J.B. Hart and D. Pauly (eds.). Reinventing fisheries management. Dordrecht, Boston, London, Kluwer Academic Publishers, Fish and Fisheries Series, 23.

Sumaila, U.R. 1999 Pricing down marine food webs. Keynote. pp. 13-15 In: Pauly, D., V. Christensen and L. Coelho (eds.). Proceedings of the EXPO'98 Conference on Ocean 
Food Webs and Economic Productivity. Lisbon, Portugal, 1-3 July 1998. ACP-EU Fish.Res.Rep., (5).

Sumaila, U.R., R. Chuenpagdee \& M. Vasconcellos (eds.) 2000. Proceedings of the INCO-DC International Workshop on Markets, Global Fisheries and Local Development. Bergen, Norway, 22-23 March 1999. ACP-EU Fish.Res.Rep., (7):115 p.

Viegas, T. 1999 Research for development: a New Deal. Int.J.Sustain.Dev.,2(3):377-381.

Walters, C. 1998 Designing fisheries management systems that do not depend upon accurate stock assessment. Chapter 21 pp. 279-288 In: Pitcher, T.J., P.J.B. Hart and D. Pauly (eds.). Reinventing fisheries management. Dordrecht, Boston, London, Kluwer Academic Publishers, Fish and Fisheries Series, 23.

Watson, R. and D. Pauly, 2001 Systematic distortions in world fisheries catch trends. Nature, 414:534-536 